\title{
Hypogammaglobulinemia with Nodular Lymphoid Hyperplasia of the Small Intestine
}

\author{
Kazumi Arikawa, M D, Hitoshi Asakura, M D, Yoichi Ichikawa, M D, \\ Tohru Aвe, M D, Mitsuo Homma, M D
}

The Department of Medicine, School of Medicine, Keio University, Tokyo

\begin{abstract}
A case of hypogammaglobulinemia with nodular lymphoid hyperplasia of the small intestine was presented with its immunological analysis. A peroral biopsy of the proximal jejunum demonstrated enlarged lymphoid follicles with large germinal centers. Only a few plasma cells were observed. Serum $\operatorname{IgG}$ and $\operatorname{IgM}$ were markedly reduced, $\operatorname{Ig} A, \operatorname{IgD}$ and $\operatorname{IgM}$ could not be traced. Secretory $\operatorname{IgA}$ was absent in saliva, while normal amount of secretory component was present. Peripheral B-lymphocytes (B-cells) enumerated by surface immunoglobulin receptors were rather increased while B-cells determined by $\mathbb{C}_{3}$ receptors were markedly decreased. Peripheral T-lymphocytes measured by sheep red blood cell rosette formation were increased in number, but their function was depressed as judged by the response to PHA. The pathogenesis of this disorder was discussed, reviewing 27 cases of this syndrome so far reported.
\end{abstract}

Key Words: Primary immunodeficiency, primary acquired hypogammaglobulinemia, secretory IgA, secretory component, IgE, lymphocytic subpopulation, B-lymphocyte, surface immunoglobulin reeceptor, $\mathrm{C}_{3}$ receptor T-lymphocyte

Among the primary immunodeficient disorders, nodular lymphnoid hyperplasia $(\mathrm{NLH})$ of the small intestine in association with primary acquired hypogammaglobulinemia $(\mathrm{PAH})$ is very unique for the coexistence of apparently conflicting two events in a patient; marked decrease in serum immunoglobulins and the prominent lymphoid follicle enlargement occurring in the intestinal mucosa. This discrepancy is very intriguing, since detailed investigation of defects may provide a deeper insight into the pathogenesis of immunodeficient disorders, and hence into the mechanism of immune system per se. This reports a typical case of this syndrome with its immunological analysis.

\footnotetext{
Received for publication January 25, 1977.

Reprints request to: Yoichi Ichikawa, Department of Medicine, Keio University Hospital, 35 Shinanomachi, Shinjuku, Tokyo, 160, Japan.
}

\section{CASE REPORT}

MH, a 37-year-old Japanese female was admitted to a hospital for the treatment of pneumonia and then refered to Keio University Hospital for the evaluation of hypogammaglobulinemia on May, 26, 1973. She had a 5-year history of recurrent respiratory tract infections, diarrhea and vomiting. She had been well until May, 1968, when she suffered from bacterial pneumonia. Since that time she had experienced 12 episodes of pneumonia. Diarrhea and vomiting, which were almost always accompanied with pneumonia, responded well to antibiotic treatment. She also began to note conjunctival injection and flow of tears precipitated by fatigue.

Past history was unremarkable except for acute appendicitis and appendectomy at age 21. Tuberculin test had changed to 
positive at age 7 . She had experienced abortion twice. Her third pregnancy was normal, delivering without complications of a healthy female infant in 1970 .

Her mother died at age 35 of lung tuberculosis.

On physical examination, the patient was of average build and fairly well nourished, $156 \mathrm{~cm}$ tall and weighted $56 \mathrm{~kg}$. The blood pressure was $110 / 66 \mathrm{mmHg}$, the pulse 84 and regular. The left palatal tonsil was moderately enlarged. No lymph nodes were palpable on general examination. The findings of the heart and the lungs were within normal limits. The liver edge was palpable two fingerbreadth beneath the left costal margin. Multiple verrucous exanthemas were observed on the dorsum of the hands.

\section{LABORATORY STUDIES}

General. The hemoglobin value was $10.9 \mathrm{~g} / 100 \mathrm{ml}$, red blood cell count $429 \times 10^{4} /$ $\mathrm{mm}^{3}$ and the white blood cell count was 6,700 with a normal differentials and normal number of platlets. Examination of bone marrow showed $27 \times 10^{4}$ nucleated cells per $\mathrm{mm}^{3}$, and a granulocytic erythroid ratio of 2.0, mature plasma cells were markedly reduced to $1,080 / \mathrm{mm}^{3}$.

The urinalysis was normal, as were serum electrolytes, serum and urinary amylases, and liver function studies except for flocculation tests. A thymol turbidity test was 0.1, and a zine turbidity test 0.6. A chest x-ray film showed consolidation of the right middle lobe. The findings of spirometry were within normal limits.

Examination of the stools revealed no blood, bacterial pathogens, or parasites including Giardia. Gastric analysis revealed normal acidity. D-xylose absorption test showed 39.6\% excretion in urine during 5 hours after the ingestion of the sugar (normal : $20 \%$ or more). A fecal fat determination of a 3-day specimen, using ${ }^{131} \mathrm{I}$ triolein, showed 20.4\% excretion (normal: $4 \%$ or less).

Serial upper gastrointestinal x-ray films

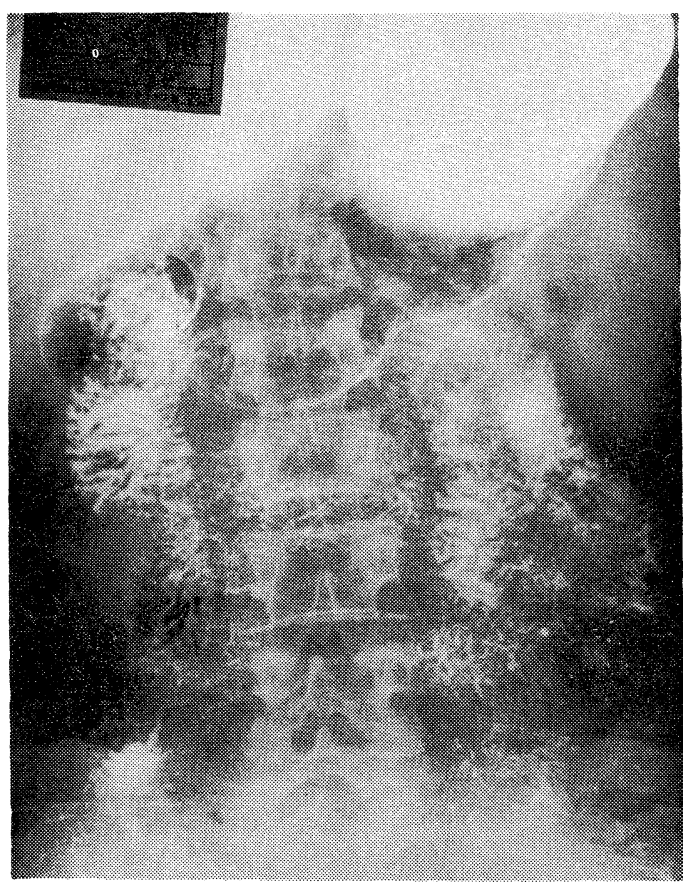

Fig. 1. Small bowel x-ray showing multiple small nodular filling defects involving most part of the small intestine.

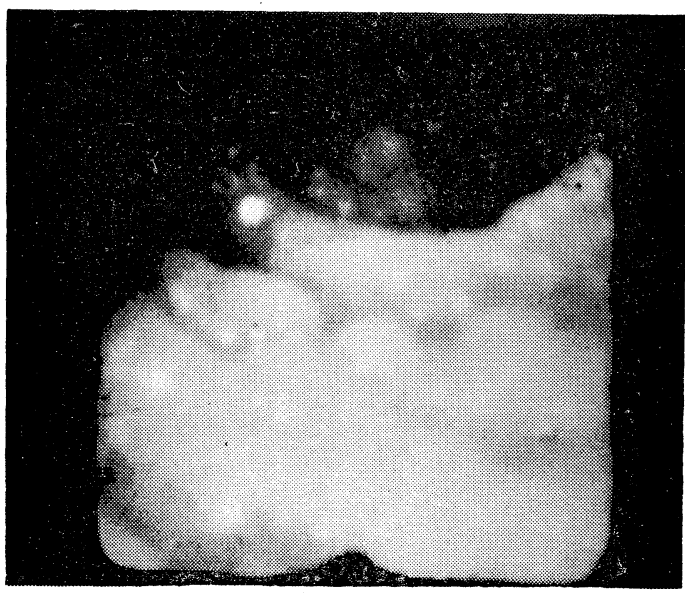

Fig. 2. Endoscopic examination of the jejunum (10cm distal from duodenojejunal flexsure). Multiple $3-5 \mathrm{~mm}$ polypoid lesions are diffusely present.

demonstrated the pattern of so called "ironed out rugae" of the stomach, the finding consistent with atrophic gastritis. Most part of the small intestine, from the descending loop of the duodenum to the terminal ileum, was studded with multiple 


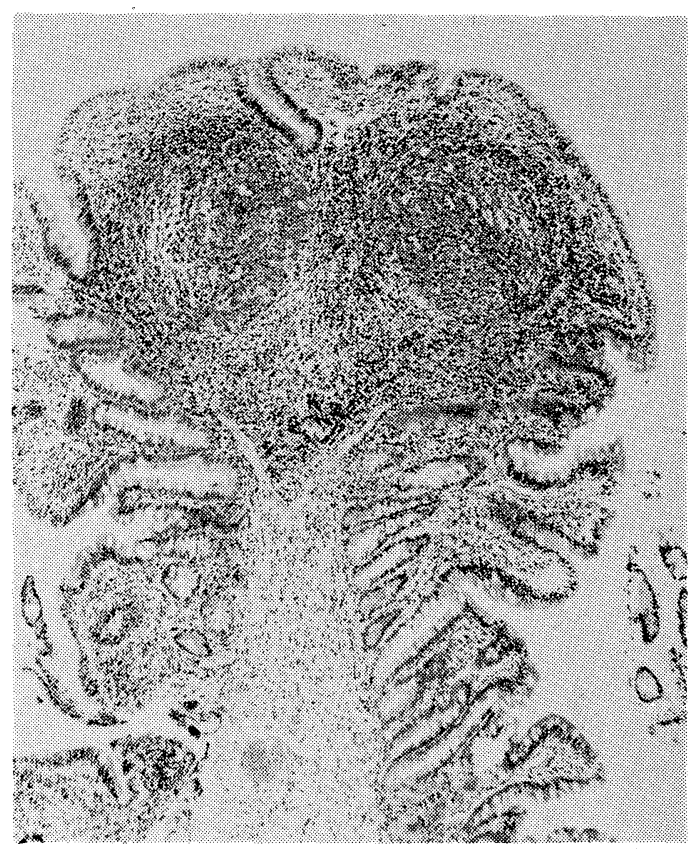

Fig. 3. Photomicrograph of a jejunal biopsy specimen showing enlarged lymphoid follicles within the lamina propria. The overlying villae are flattened.

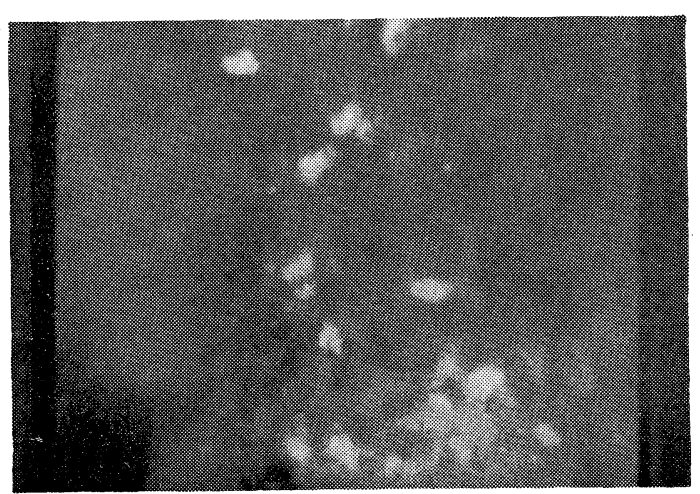

Fig. 4. Fluorescent staining of a jejunal biopsy specimen. Rather increased numbers of IgE containing plasma cells are observed. This staining was performed using FITG labelled rabitt anti human IgG (Teizo, Japan).

small nodular filling defects (Fig. 1). Barium enema revealed the existence of this nodularity also in cecum, ascending, transverse, and descending colons. The nodules in colon became somewhat more irregular in shape and less in number than those of

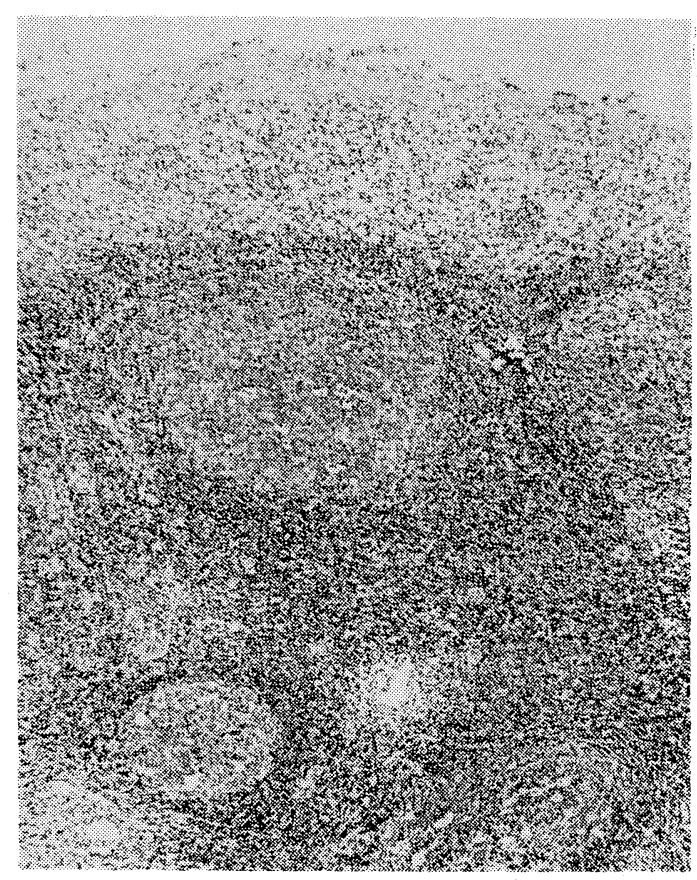

Fig. 5. Photomicrograph of a tonsillar biopsy specimen showing lymphoid follicles with well developed germinal centers.

small intestine. Haustration in the affected segments of the colon were lost. No abnormality was recognized in the rectosigmoid.

Endoscopic examination demonstrated multiple 3-5 mm polypoid lesions diffusely present in duodenum and jejunum (Fig. 2). The polyps were light-yellowish in color, their surfaces were smooth without ulcerations.

A peroral biopsy of the proximal jejunum demonstrated enlarged lymphoid follicles with large germinal centers within the lamina propria (Fig. 3), causing flattening of the villous pattern of the overlying mucosa. Elsewhere in the lamina propria, the moderate lymphocytic infiltrate was observed. Only a few plasma cells were present. Mucosal epithelial cells were normal, with no signs of atrophy. Immunofluorescent antibody analysis of this biopsy specimen revealed paucity of immunofluorescent positive mucosal cells when stained with immunoglobulin $\mathrm{G}(\mathrm{IgG}), \operatorname{IgA}$, and $\operatorname{Ig} \mathrm{M}$, respectively. $\operatorname{IgE}$ containing 


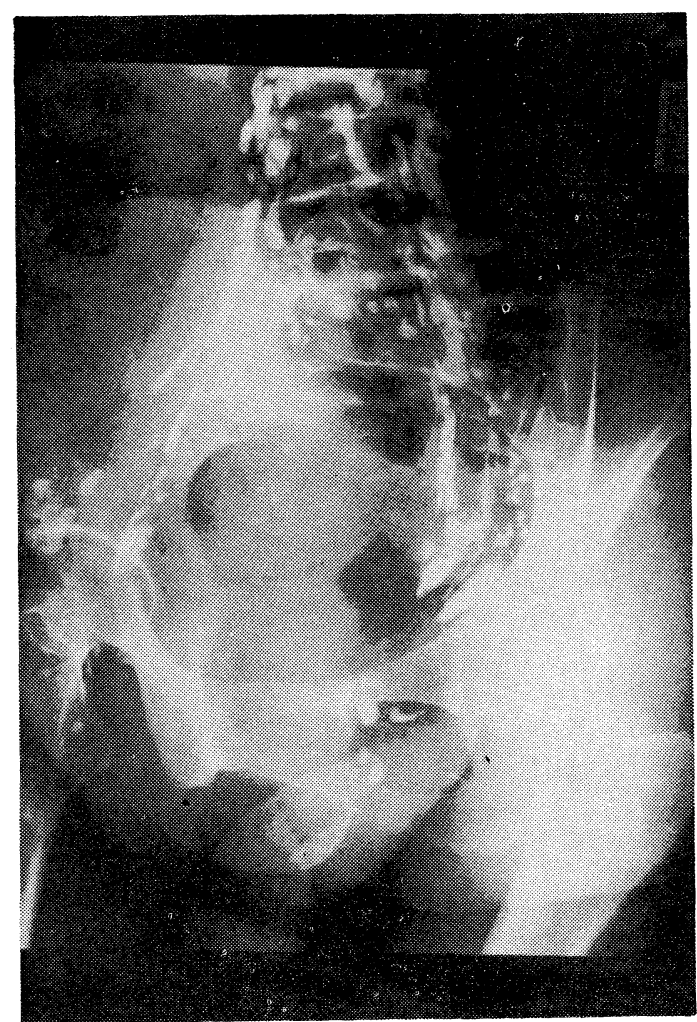

Fig. 6. Lymphangiography. Rather increased numbers of paraaortic and iliac lymph node chains are demonstrated.

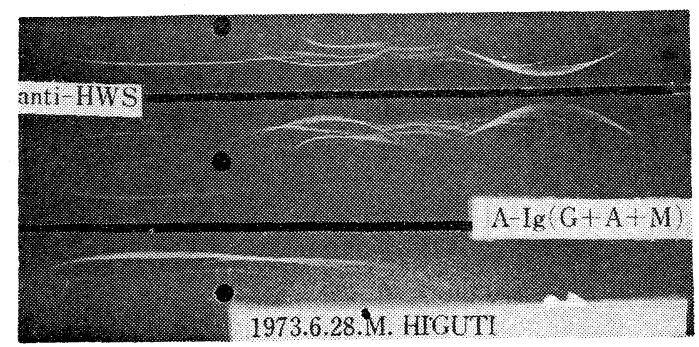

Fig. 7. Immunoelectrophoresis of patient's serum. Top and bottom wells contain normal control serum and central well contains patient's serum.

Anti-HWS : anti human's whole serum.

$A-\operatorname{Ig}(G+A+M)$ : anti human $\operatorname{Ig} G+\operatorname{Ig} A$ $+\operatorname{Ig} \mathrm{M}$.

Patient's serum shows decreased intensity of IgG line, $\operatorname{Ig} \mathrm{A}$ and $\operatorname{Ig} \mathrm{M}$ lines cannot be traced.

plasma cells, however, were present in rather increased numbers (Fig. 4).

Tonsillar biopsy specimen also con-

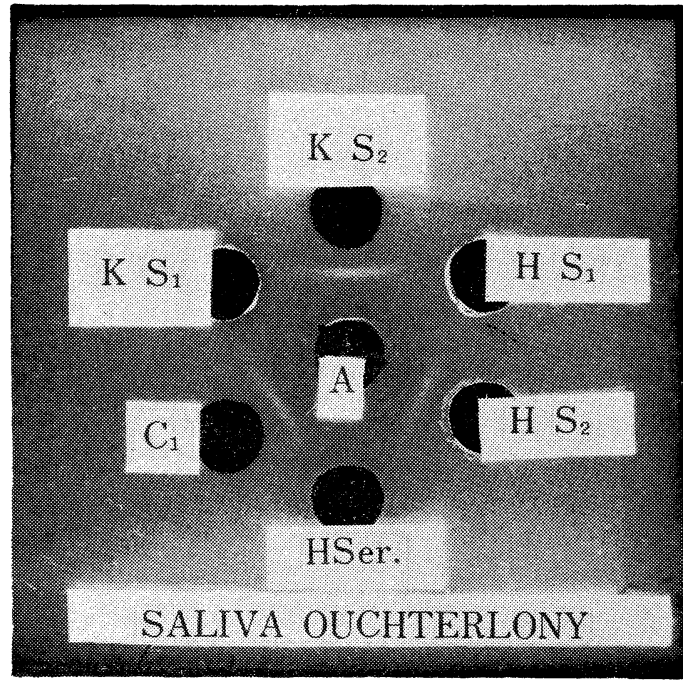

Fig. \&a. Saliva IgA analysed by immunodifusion method

A : anti-IgA.

$\mathrm{HS}_{1}$ : concentrated saliva from the patient.

HSer: patient's whole serum.

$\mathrm{KS}_{1}$, KSer: concentrated saliva $\left(\mathrm{KS}_{1}\right)$ and whole serum (KSer) of a subject with primary acquired hypogammaglobulinemia.

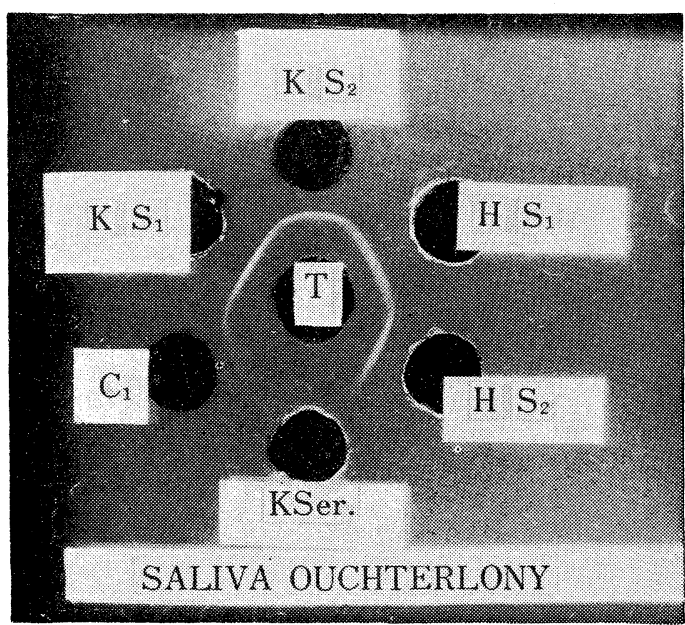

Fig. 8b. Secretory component in saliva analysed by immunodiffusion method.

$\mathrm{T}$ : anti-secretory component.

Other abbreviations were same as described in the legend of Fig. 8a.

tained lymphoid follicles with well developed germinal centers (Fig. 5).

Lymphangiography visualized increased numbers of paraaortic and iliac lymph node 
Table 1. Humoral Antibody

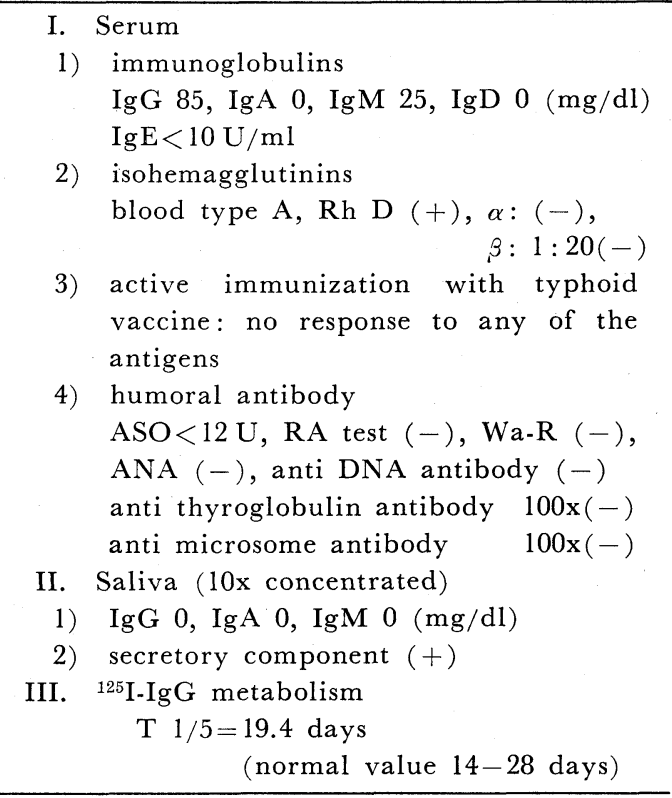

Table 2. Cellular Immunity and Lymphocytic Subpopulation

I. Cellular immunity

1) PPDS intracutaneous reaction (-)

2) DNGB patch test $0.1 \%(-)$ $0.01 \%(-)$

3) in vitro response of lymphocytes to PHA Blastoid transformation: $0 \%$

Incorporation of $3 \mathrm{H}$-Thymidine into DNA; stimulation index $1.8(4.56 \pm 0.54)$

II. Lymphocyte subpopulation

1) Ig-bearing lymphocytes

$\begin{array}{lrr}\text { IgG } & 21.5 \% & (8.9 \pm 3.0) \\ \text { IgA } & 3.3 \% & (2.7 \pm 1.9) \\ \text { IgM } & 2.3 \% & (5.4 \pm 2.1)\end{array}$

2) EAC binding lymphocytes

May 31, $1973 \quad 3 \%(16.7 \pm 2.8)$

Feb 22, $1974 \quad 3 \%(16.7 \pm 2.8)$

3) Sheep erythrocyte binding lymphocytes $71 \%(52.2 \pm 6.4)$

*normal value ( ): Mean $\pm 1 \mathrm{SD}$

chains. The size of lymph node was rather small, with no pathological defect or deformity (Fig. 6).

Strangular shaped thymus was clearly demonstrated by pneumomediastinography, and there were no findings suggesting thymoma.

Immunological date were summarized in Table 1 and 2. Concentrations of serum immunoglobulin $\mathrm{G}$ ( $\operatorname{IgG}), \operatorname{IgA}, \operatorname{IgM}$ and $\mathrm{IgD}$ were measured by Ouchterlony method, and serum $\operatorname{IgE}$ by radio-immunoassay using "Phadebas IgE test" (Pharmacia, Sweden). Serum IgG and IgM were markedly reduced, IgA, IgD and IgE were not detectable. The result of immunoelectrophoresis of patient's serum (Fig. 7) was consistent with these findings. Serum isohemagglutinin titers, both $\alpha$ and $\beta$, were less than $1: 20$. After active immunization with Salmonella typhosa vaccine, patient's serum showed no significantly elevated titers to any of the Salmonella antigens. Tests for antinuclear, anti DNA, antithyroglobulin and anti-microsome antibody gave negative results. Analysis of ten times concentrate of stimulated saliva by Ouchterlony plate technique revealed the presence of secretory component, while IgA, IgG and IgM were not detected (Fig. 8-a, b). Plasma $\mathrm{T} 1 / 2$ of radioiodinated IgG (1) was within normal limits. Both PPDS intradermal skin test and DNGB patch test were negative. The in vitro response of patients' lymphocytes to PHA was assessed by blastoid transformation and by incorporation of ${ }^{3} \mathrm{H}$-thymidine into DNA. Both responses were markedly depressed.

Peripheral blood lymphocytes, especially bone marrow derived lymphocytes (B-cells) were measured by surface immunoglobulin (Ig) receptors and by $\mathrm{C}_{3}$ receptors (EAC-binding lymphocytes) (2). These two methods gave entirely different results; Ig-bearing lymphocytes were increased as compared with the control cells, while EAC-binding lymphocytes were markedly diminished. Thymus derived lymphocytes (T-cells), measured by sheep red blood cell rosette formation (2), were increased in number as compared with the control cells.

Hospital course: After treatment with $2.0 \mathrm{~g}$ of cephalosporin daily, the chest x-ray findings improved and the splenomegaly disappeared. She was discharged after administration of $90 \mathrm{ml}$ of human $\gamma$-globulin 
$(150 \mathrm{mg} / \mathrm{ml})$ as an initial dose. Now she is doing well with monthly injection of $30 \mathrm{ml}$ of $\gamma$-globulin.

\section{DISCUSSION}

In 1966, Hermans et al (3) reported eight patients characterized by 1) nodular lymphoid hyperplasia (NLH) of the small intestine, 2) dysgammaglobulinemia with very low level of IgA and IgM, and moderate decrease in $\operatorname{IgG}, 3$ ) increased susceptibility to infection, 4) diarrhea, or moderate steatorrhea, 5) presence of Giardia lambria in the feces, and attempted to define these associations as a new clinical syndrome under the title "dysgammaglobulinemia with nodular lymphoid hyperplasia of the small intestine".

As for the item 2), later it became clear that that variable immunoglobulin deficiency patterns indistinguishable from idiopathic hypogammaglobulinemia were associated with NLH of the small intestine. Therefore the case reported here coincided with the clinical, immunological and histopathological characteristics described above. To date, there have been documented 27 cases of NLH of the small intestine in the literature (3), (5)-(20).

Among the reported cases, most common serum immunoglobulin pattern was that of hypogammaglobulinemia, with reductions in all three major immunoglobulins. The others were each one case of type I (12) and type II (13) dysgammaglobulinemia, and two cases of selective IgA deficiency (3), (10). The lack in IgA seems to be the single humoral immune defect common to all reported cases of this syndrome.

There were several reports of NLH which occured only in the terminal ileum (21) or only in the colon (22). Whereas the patients with this "localized" NLH exibited no immunodeficient states, NLH of the proximal small intestine (i. e. duodenum and jejunum), was always accompanied by some type of humoral immunodeficiency with absence or decrease in serum $\operatorname{Ig} \mathrm{A}$. This is very suggestive when we consider the peculiar nature of $\operatorname{IgA}$. Though $\operatorname{IgA}$ represents a relatively small fraction of the serum immunoglobulins, it is the predominant species in most external secretions such as saliva, nasal or intestinal fluids, and is considered to play an important role in local mucosal immunity (23), (24).

$\operatorname{IgA}$ in external secretions has a different structure from that in serum: this "secretory IgA" consists of two $7 \mathrm{~S} \operatorname{IgA}$ monomers plus a non-immunoglobulin glycoprotein called secretory component (SC). In this case, immunological analysis of concentrated saliva revealed normal amount of free SC and absence of secretory IgA. Among the reported cases, secretory immuno-globulins have been assessed in 7 cases (including this report) for saliva, duodenal fluid, or both (9), (15)-(17). The absence or marked decrease in secretory $\operatorname{Ig} \mathrm{A}$ is the common feature of all these 7 cases. These data suggests that the lack of secretory $\operatorname{IgA}$ in external secretions may play an important role in the genesis of this syndrome.

Interestingly enough, increased numbers of IgE containing plasma cells were found in the jejunal biopsy specimen of this patient despite her very low serum IgE level. The similar discrepancy has been reported in two cases (25), (26). These three cases had following two common features; the presence of gastrointestinal symptoms and the lack of $\operatorname{IgA}$ in serum and in various mucosal secretions. According to Tada and Ishizaka (27), IgE containing plasma cells are predominant in regional lymph nodes, respiratory and gastrointestinal mucosa, but were scarce in subcutaneous lymph nodes and in spleen. This is the similar distribution to that of $\operatorname{IgA}$ containing plasma cells. Rather increased numbers of IgE containing plasma cells in gastro-intestinal mucosa observed in this case may be explained as an allergic phenomenon induced by lack of secretory IgA which permits the mucosal surface to be continuously exposed to excessive amount of various antigenic stimulations.

In congenital $\mathrm{x}$-linked agammaglobuli- 
nemia, all recognizable elements of plasma cell line are dificient with severely impaired lymphoid follicle development in various lymphoid tissues. To be contrasted is this case, in which normal or even hyperplastic germinal centers, NLH of the small intestine are observed. It is now generally admitted that, in contrast to congenital $x$ linked agammaglobulinemia, primary acquired hypogammaglobulinemia including the syndrome of NLH of the small intestine is a heterogeneous disease resulting from defects occuring at various stages of maturation pathways of the B-cell (18), (28) -(30). Enumerations of B-lymphocytes in such patients has led to the delineation of two different patterns, ie, normal or increased, and decreased number of $\mathrm{B}$ cells (31). Patients with NLH of the small intestine belong to the former, as is shown in this case by increased number of immunoglobulin bearing lymphocytes (IBL).

On the other hand, the percent of lymphocytes identified as B-cells by the EAC3 rosette technique, EAC-bearing lymphocytes (EBL), was significantly decreased in this patient. According to Ross et al (32), the populations of B-cells determined simultaneously by two methods did not agree completely, though mainly overlap. Nine immunodeficient patients have been reported in whom these two different B-cell markers agreed very closely (less than 5 per cent difference) (33). However, the apparent discordance between IBL and EBL has been observed in some cases af chronic lymphatic leukemia and SLE (32), (34). In our patient, the marked discrepancy in two methods, ascertained by reexamination, implicates the possibility that B-lymphocytes may have some unknown qualitative abnormality in addition to the maturation defect.

As for cellular immunity in this case, peripheral T-lymphocytes were increased in number, but their function was depressed as judged by the response to PHA.

One possible explanation for how NLH of the small intestine is formed is as the following; the lack of secretary IgA ren- dered continuous excessive antigenic stimulations to the intestinal mucosa of the patient. The immature B-cells (18) respond to such antigens by proliferation constituting the NHL of the intestinal mucosa. But they lack the ability of antibody antibody synthesis and/or its secretion. Absence of negative feedback for lymphocytic proliferation by immunoglobulin (18) may also contribute the excessive proliferation. The majority of the cases of this syndrome accompany some kind of cellular immunological defects, though its association with the pathogenesis is yet quite obscure. In view of the importance of T-cell and B-cell interactions in the antibody response, further investigation will probably prove some role of cellular immunological defect in the pathogenesis of this syndrome.

ACKNOWLEDGEMENTS: We are indebted to Dr Akira Ono performing immunofluorescent study of peripheral B-lymphocytes, to Dr Takeshi Kawai for radiommunoassay of $\operatorname{IgE}$, and to members of department or radiology, Keio University Hospital, for performing gastro-intestinal series and for instructive comments. We are also indebted to Drs Atuo Mikata, Takeshi Kanno and Shojiro Kano of the department of clinical laboratory for the detailed histological and biochemical analyses.

\section{REFERENCES}

1) Wells JV, Fudenberg $\mathrm{HH}$ : Metabolism of radioiodinated $\mathrm{IgG}$ in patients with abnormal serum IgG levels. II Hypogammaglobulinemia. Clin exp Immunol 9: 775, 1971.

2) Jondal M, Holm G, Wigzell H: Surface markers on human $\mathrm{T}$ and $\mathrm{B}$ lymphocytes. I J Exp Med 136: 207, 1972 .

3) Hermans PE, Huizenga KA, Hoffman HN, Brown AL, Markowitz $\mathrm{H}$ : Dysgammaglobulinemia associated with nodular lymphoid hyperplasia of the small intestine. Am J Med 40; 78, 1966.

4) Penny R: Nodular lymphoid hyperplasia of the small intestine and hypogammaglobulinemia. Gastroenterology 56: 982, 1969.

5) Firkin BG, Blackburn GR: Congenital and acquired aggamaglobulinemia. A report of four caseś QJ Med 27 : 187, 1958.

6) Frik W, Heinkel K, Zeitler G: Vermehrung 
und Hyperplasia von Lymphfollikeln als Ursache granulärer Füllungsdefekte im Röntgenbild des gesamten Dünndarms. Fortschur Geb Röntgenbild des gesamten Dünndarms. Fortschur Geb Röntgenstr Nuklearmed 99: 65, 1963.

7) Grise JW: Dysgammaglobulinemia with nodular lymphoid hyperplasia of the small intestine. Radiology 90 : 579, 1968.

8) Kirkpatrik CH, Waxman D, Smith OD, Schmike RN: Hypogammaglobulinemia with nodular lymphods hyperplasia of the small bowel. Arch Intern Med 121: 273, 1968.

9) Penny R, Glasson R, Goulston K, McCredie K, Thorpe M, Wells J: Nodular lymphoid hyperplasia of the small intestine associated with hypogammaglobulinemia. Proc the Third Asian Pacific Congress of Gastroenterology, p 46, 1968.

10) Gryboski JD, Self TW, Clement A, Herskovic $T$ : Selective immunoglobulin A deficiency and intestinal nodular lymphoid hyperplasia: Correction of diarrhea with antibiotics and plasma. Pediatrics 42: 833, 1968.

11) Bird DC, Jacobs JB, Silbiger M, Wolff SM : Hypogammaglobulinemia with nodular lymphoid hyperplasia of the intestine. Radiology 92 : 1535, 1969.

12) Goldstein GW, Krivit WJ, Hong R: Hypoimmunoglobulin G, Hyperimmunoglobulin M, intestinal nodular hyperplasia, and thrombocytopenia. An unusual association. Arch Dis Child 44:621, 1969.

13) Anderson FL, Pellegrino ED, Schaefer JW : Dysgammaglobulinemia associated with malabsorption and tetany. Digestive Diseases $15: 279,1970$.

14) Davis SD, Eidelman S, Lcop JW: Nodular lymphoid hyper-plasia of the small intestine and sarcoidosis. Arch Intern Med 126:668, 1970.

15) Dubois RS, Roy CC, Flugintini VA, Merrill DA, Murray RL: Disaccharidase deficiency in children with immunologic deficits. J Pediata $76: 377,1970$.

16) Michaels DL, Go S, Humbert JR, Stewart JM, Ellis EF : Intestinal nodular lymphoid hyperplasia, hypogammaglobulinemia, and hematologic abnormalitis in a child with a ring 18 chromosome. J Pediatr 79: 80, 1971.

17) Johnson BL, Goldberg LS, Pops MA,
Weiner $M$ : Clinical and immunological studies in a case of nodular lymphoid hyperplasia of the small bowel. Gastroenterology 61: 369, 1971 .

18) Cooper MD, Lawton AR: Agammaglobulinemia with B-lymphocytes. Specific defect of plasma cell differentiation. Lancet 2: 791, 1971.

19) Adjukiewicz AB, Youngs GR, Bouchier IAD. Nodular lymphoid hyperplasia with hypogammaglobulinemia. Gut 13:589, 1972.

20) Takashima $T$, Okimura $T$ : Roentgenologic features of the small intestine in agammaglobulinemia. Stomach and Intestine 7: 1029, 1972.

21) Fieber SS, Schaefer HJ: Lymphoid hyperplasia of the terminal ileum-a clinical entity? Gastroenterology $50:$ 83, 1966.

22) Capitana MA, Kirkpatric JA: Lymphoid hyperplasia of the colon in children. Roentgen observations. Radiology $94: 323,1970$.

23) Tomasi TB: Secretory immunoglobulins. N Eng J Med 287: 500, 1972.

24) Bull DM, Tomasi TB: Deficiency of immunoglobulin A in intestinal disease. Gastroenterology $54: 313,1968$.

25) Brown WR, Butterfield D, Savage D, Tada $\mathrm{T}$ : Clinical, microbiological and immunological studies in patients with immunoglobulin deficiencies and gastrointestinal disorders. Gut 13: 441, 1972.

26) Masuda $M$ : The pathological physiology of the small intestine. Jap J Med 62: 719, 1973.

27) Tada $T$, Ishizaka $\mathrm{K}$ : Distribution of $\gamma-\mathrm{E}$ forming cells in lymphoid tissues of the human and monkey. J Immun 104 : 377, 1970.

28) Preud'homme JL, Seligmann M: Primary immunodeficiency with increased numbers of circulating B lymphocytes contrasting with increased numbers of circulating B lymphocytes contrasting with hypogammaglobulinemia. Lancet 1: 442, 1972.

29) Aiuti F, Lacava V, Fiorilli M: B lymphocytes in agammaglobulinemia. Lancet 2: 761, 1972.

30) Choi YS, Biggar WD, Good RA : Biosynthesis and secretion of immunoglobulins by peripheral blood lymphocytes in severe hypogammaglobulinemia. Lancet 1: 1149, 1972.

31) Cooper MD, Fault PW, Fudenberg $\mathrm{HH}$, Good RA, Hitzig W, Kunkel H, Rosen FS, Seligman M, Soothill J, Wedgewood RJ : Classification of primary immunodeficiencies. 
N Eng J Med 288 : 966, 1973.

32) Ross GD, Rabellino EM, Polley MJ, Grey HM : Combined studies of complement receptor and surface immunoglobulinbearing cells and sheep erythrocyte rosette-forming cells in normal and leukemic human lymphocytes. J Clin Invest 52: 377, 1973.

33) Geha RS, Schneeberger E, Merler E, Rosen
FS : Heterogeneity of "acquired" or common variable agammaglobulinemia. $\mathrm{N}$ Eng $\mathrm{J}$ Med 291: 1, 1974.

34) Messner RP, Lindström FD, Williams RC: Peripheral blood Iymphocyte cell surface markers during the course of systemic lupus erythematosus. J Clin Invest $52: 3046,1973$. 